\title{
Temporal variation, growth and natural mortality of two species of mojarras (Perciformes: Gerreidae) from a tropical coastal lagoon: La Carbonera, Yucatan, Mexico
}

\section{Variación temporal, crecimiento y mortalidad natural de dos especies de mojarras (Perciformes: Gerreidae) de una laguna costera tropical: La Carbonera, Yucatán, México}

\author{
José Luis Bonilla-Gómez ${ }^{1 *}$, Maribel Badillo-Alemán ${ }^{2}$, Alfredo Gallardo-Torres ${ }^{2}$ and Xavier \\ Chiappa-Carrara ${ }^{2}$
}

\begin{abstract}
This study reports seasonal variation, growth parameters and natural mortality for Eucinostomus gula and Eucinostomus argenteus inhabiting La Carbonera, a tropical coastal lagoon on the northwestern coast of the Yucatan Peninsula, Mexico. Specimens were collected between April 2009 and March 2010. A total of 2700 organisms of $E$. gula ( $>80 \%$ in rainy season ) and 1577 organisms of E. argenteus ( $>50 \%$ in dry season) were collected during the study period. Length-weight relationship (LWR) obtained was $W=8.323 E-03$ $L t^{2.92}$ in $E$. argenteus and $W=7.314 E-03 L t^{2.92}$ in E. gula. Growth parameters of von Bertalanffy growth function (VBGF) by length frequency analysis were in $E$. argenteus: $L_{\infty}=13.65 \mathrm{~cm}, k=0.54$ year ${ }^{-1}$ and $t_{0}$ $=-0.37$ years; and in E. gula: $L_{\infty}=12.60 \mathrm{~cm}, k=0.68$ year $^{-1}$ and $t_{0}=-0.28$ years. Additionally, estimated natural mortality in E. gula was 1.50 year $^{-1}$ and in E. argenteus was 1.9 year $^{-1}$. This study presents the first estimation for both species of model parameters, growth performance index and mortality for the Yucatan Peninsula, which is relevant for the proper implementation of conservation measures for E. gula and $E$. argenteus in an important coastal zone of the Yucatan Peninsula.
\end{abstract}

Keywords: Eucinostomus gula, Eucinostomus argenteus, length-weight relationship, natural mortality.

\section{RESUMEN}

Se reporta la la variación temporal, parámetros de crecimiento y mortalidad natural para Eucinostomus gula y Eucinostomus argenteus que habita en la laguna costera tropical La Carbonera, al noroeste de la península de Yucatán, México. Los especímenes fueron colectados entre abril 2009 a marzo 2010. Un total de 2700 organismos de E. gula ( $>80 \%$ en estación lluviosa) y 1577 organismos de E. argenteus $(>50 \%$ en estación seca) fueron colectados durante el período de estudio. Se determinó la relación peso-longitud (RPL) como: $P=8.323 E-03 L t^{2.92}$ en E. agenteus y $P=7.314 E-03 L t^{2.92}$ en E. gula. Para E. argenteus los parámetros de crecimiento de la ecuación de crecimiento de von Bertalanffy (ECVB) fueron: $L_{\infty}=13.65 \mathrm{~cm}, k=0.54$ año${ }^{1}$ y $t_{0}=-0.37$ años; mientras que para $E$. gula fueron: $L_{\infty}=12.60 \mathrm{~cm}, k=0.68$ año ${ }^{-1}$ y $t_{0}=-0.28$ años. La mortalidad natural en E. gula fue $1.50 \mathrm{año}^{-1}$ y en $E$. argenteus fue $1.9 \mathrm{año}^{-1}$. Este estudio presenta la primera estimación para ambas especies de los modelos de crecimiento, el índice del desempeño de crecimiento y mortalidad natural para la península de Yucatán, lo que es relevante para la adecuada implementación de medidas de conservación de E. gula y E. argenteus en una valiosa zona costera de la península de Yucatán.

Palabras claves: Eucinostomus gula, Eucinostomus argenteus, relación talla-peso, mortalidad natural.

\footnotetext{
Posgrado en Ciencias del Mar y Limnología, Universidad Nacional Autónoma de México. Circuito exterior S/N, Ciudad Universitaria, México D. F., México. C. P. 04510. jose.bonilla@comunidad.unam.mx*

2 Unidad Multidisciplinaria de Docencia e Investigación de Sisal (UMDI-Sisal, UNAM). Puerto de Abrigo s/n, Sisal, Hunucmá, Yucatán, México. C.P.97356.maribaam@yahoo.com, gallalf@yahoo.com, xcc@ciencias.unam.mx
}

Recibido 4 II 2013

Aceptado 16 VI 2013

DOI: http://dx.doi.org/10.15359/revmar.5.4 


\section{INTRODUCTION}

Juvenile fish growth is considered one of the most important factors contributing to future recruitment of adult populations within a habitat. Length and weight relationship (LWR) parameters $(a$ and $b)$ are necessary variables to understand the dynamics of a fish population (Pitcher \& Hart, 1982), just as environmental factors are key in understanding the importance of a population in a particular habitat (Shervette et al. 2007) and in a particular season (Castillo-Rivera et al. 2002).

The Gerreidae family, colloquially known as mojarras, is a marineeuryhaline species (Godefroid et al. 2001) widely distributed in tropical and subtropical latitudes, constituting an abundant resource of commercial importance in Mexican coastal lagoons (Ordóñez-López \& GarcíaHernández, 2005). The silver mojarra, Eucinostomus argenteus, and the jenny mojarra, Eucinostomus gula, are the most abundant species in coastal lagoons influenced by freshwater seeps in the northwestern Yucatan peninsula (Vega-Cendejas et al. 2012). Although both species are not fished in the northwestern Yucatan peninsula, they are considered important for fisheries along other coastal areas of the Gulf of Mexico, the Caribbean, and the Atlantic (Kerschner et al. 1985).

The Yucatan peninsula has numerous coastal lagoons, whose structure and function are modified by wastewater discharge, groundwater pumping, and land use changes. La Carbonera coastal lagoon is a transitional environment between karst land and a marine habitat with highly environmental variability over short time scales. This lagoonal system is important for local fisheries and as bird habitat (e.g. rose flamingos Phoenicopterus ruber).

The aim of this study was to estimate the natural mortality and present the seasonal variation, lengthweight relationship (LWR), and growth parameters of E. gula and E. argenteus from La Carbonera lagoon in the northwestern Yucatan Peninsula.

\section{MATERIALS AND METHODS}

Study area: La Carbonera coastal lagoon lies on the northwestern Yucatan peninsula, Mexico (21 $1^{\circ} 13^{\prime}-$ $21^{\circ} 14^{\prime} \mathrm{N} ; 89^{\circ} 52^{\prime}-89^{\circ} 54^{\prime} \mathrm{W}$; Fig. 1) (Bonilla-Gómez et al. 2012). It is connected to the sea by a channel formed in 1988 by Hurricane Gilbert and is fringed with Rhizophora mangle stands and a sand barrier. The lagoon is shallow (average annual depth $\sim 0.5$ m) and covers an area of $\sim 16.5 \mathrm{~km}^{2}$. It is a very low karstic biogenic marine littoral (Batllori-Sampedro et al. 2006). Freshwater input is restricted to underground seeps and rainfall. There is a cenote (sinkhole) in the southern part of the lagoon, in a patch of mangroves. There are three climatic seasons in the area and a karstic substratum through the system with three types of sediments: sandy, rocky bed, and muddy (Lankford, 1977). 

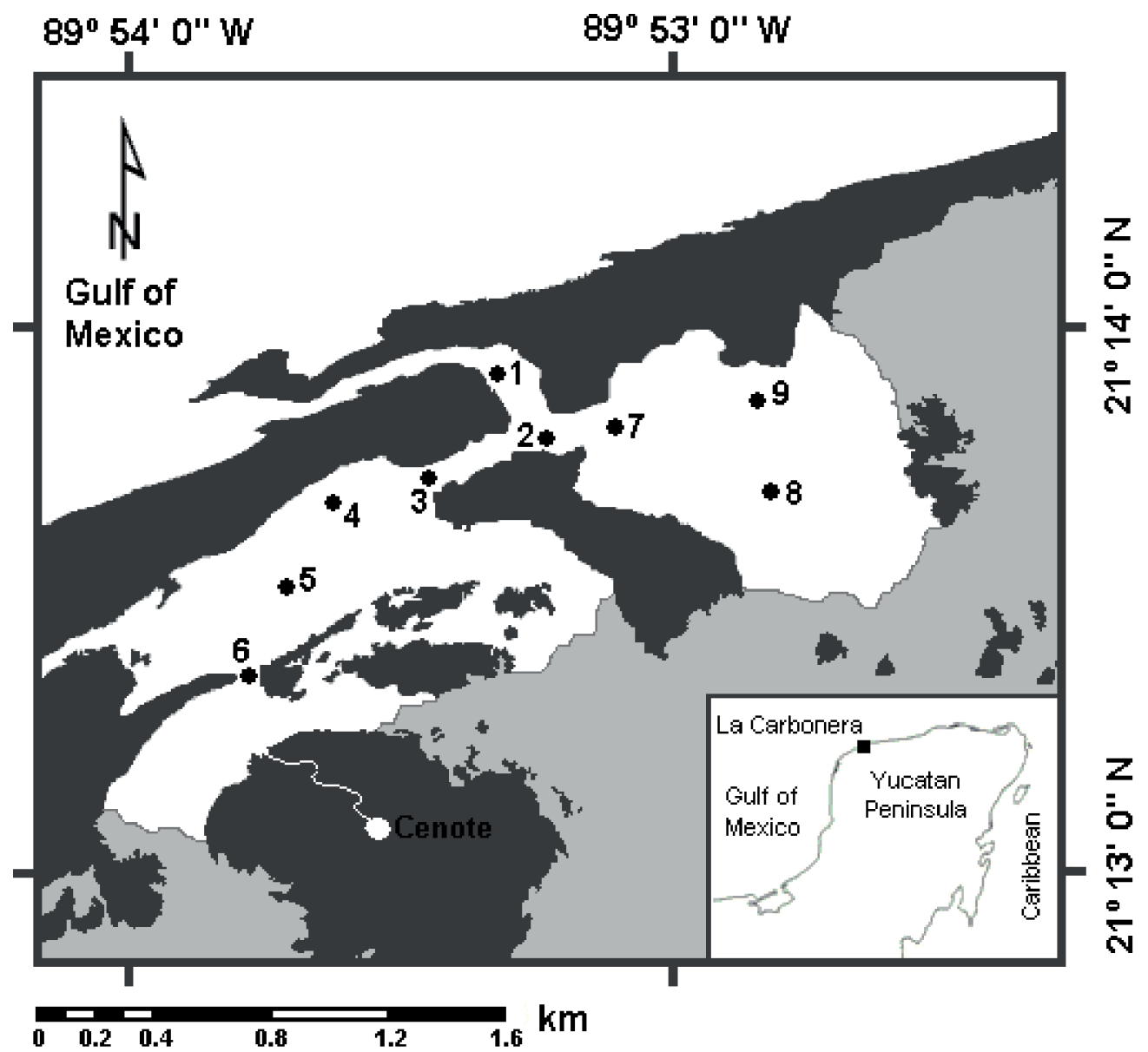

Fig. 1. Map of La Carbonera coastal lagoon with the sampling stations and the "cenote" (sinkhole). The line indicates the maximum level in the rainy season, the light black zone is the wetland, and the black spots are patches of mangroves

Fig. 1. Mapa de la laguna costera La Carbonera con las estaciones de muestreos y el cenote. La línea indica el nivel máximo en la estación lluviosa, la zona sombreada es el humedal y la zona negras son parches de manglares

Sampling and environmental data: Sampling simultaneously including fish and environmental variables was performed monthly between April 2009 and March 2010 in nine sampling stations distributed along the lagoon (nine replications per month). Water temperature $\left({ }^{\circ} \mathrm{C}\right)$ and salinity were recorded in each sampling station (measured at $30 \mathrm{~cm}$ depth) with a Yellow Springs Instrument (YSI), model 556 MPS.

Specimens were caught monthly with a beach seine net $(40 \mathrm{~m}$ long $\mathrm{x}$ $1 \mathrm{~m}$ depth $\times 1.27 \mathrm{~cm}$ stretch mesh size; Mexican government permit No. DOPA/04031/310510.1940). The sampling area was $400 \mathrm{~m}^{2}$ (40 $\mathrm{m}$ width per $10 \mathrm{~m}$ long of dragging) with one sample per station taking 2 minutes to 
drag; the net was cast once at each site for each month. All sites were sampled within a $6 \mathrm{~h}$ period during high tide and on the same day. Collected specimens were euthanized in an ice slurry, preserved in formaldehyde $(4 \%)$ and transported to the laboratory, where they were measured $( \pm 0.1 \mathrm{~mm}$ total length: $L t)$ and weighed $( \pm 0.01 \mathrm{~g}$ total weight: $W$ ).

Collected fish and environmental data were classified to analyze seasonal variations under three climatic seasons: dry (D: March-June), rainy (R: July-October), and northerly winds (locally known as nortes) (NW: November-February) according to Bonilla-Gómez et al. (2012). April 2010 was not included in this analysis. A total of 99 measurements were performed ( 9 repetitions per 11 months sampled). Total abundance (Nind $\mathrm{m}^{-2}$ ) was determined in all climatic seasons. ANOVA was used to show statistical differences in the environment and abundance data between climatic seasons.

\section{Length-weight relationship and} growth: LWR was estimated using the equation: $W=a L t^{b}$ (Sparre \& Venema, 1995), where $W$ represents weight (g), $L t$ is total length $(\mathrm{cm})$, parameter $a$ is a constant and $b$ is the slope of the model. To determine parameters $a$ and $b$, a regression analysis was conducted of the log-converted total weight and total length. The 95\% confidence intervals for $b$ (CI 95\%) and the correlation coefficient $\left(r^{2}\right)$ were calculated to determine whether the hypothetical isometric value (3) fell between these intervals (Froese, 2006). This analysis included all fish data from April 2010 with a total of 108 measurements (9 repetitions per 12 months sampled).

Parameters of the von Bertalanffy growth function (VBGF) were determined through the ELEFAN-I software included in the package FAOICLARM Fish Stock Assessment Tools (FiSAT II) (Gayanilo et al. 2005), using length frequency distribution with class intervals of $1.0 \mathrm{~cm}$ of total length. VBGF is expressed as follows: $L t=L_{\infty}$ $\left[1-\exp ^{-k(t-t)}\right]$, where $L t$ is the length at age $t, L_{\infty}$ is asymptotic length, $k$ is the growth rate $\left(\mathrm{cm} \mathrm{year}^{-1}\right)$ and $t_{0}$ is the hypothetical age of fish at length zero.

In order to assess the variability of $k$ taking into account the uncertainty in the estimation of asymptotic length, estimated values of maximum length and its $95 \%$ confidence interval from the routine Maximum Length Estimate included in FiSAT II (Gayanilo et al. 2005) were used to obtain a range of possible values for $k$. The hypothetic age at which the fish length is zero $\left(t_{0}\right)$ was calculated separately using Pauly's empirical formula (1979). The growth performance index ( $f^{\prime}$ ) used was the one proposed by Munro and Pauly (1983).

Mortality: Total instantaneous mortality rate (Z), with a $95 \%$ confidence interval, was determined by the length-converted catch curve (Pauly, 1983; 1990), which, in the absence of exploitation in the area of study, is equivalent to the instantaneous natural mortality rate $(M)$. Additionally, 
an independent estimate of $M$ was obtained using the empirical equation proposed by Pauly (1980).

\section{RESULTS}

Mean temperature found during this study ( $n=99$ measurements) was $28.6 \pm 1.6^{\circ} \mathrm{C}\left(83.48^{\circ} \mathrm{F}\right)$ and varied significantly with the different climatic seasons (ANOVA, $F=11.98, P<$ $0.05)$. Higher mean values were found during the rainy season. On the other hand, mean salinity was $35.1 \pm 5.4$ with a significant seasonal variation (ANOVA, $F=6.25 P<0.05$ ). Lower mean values were obtained when north winds prevailed (Fig 2).
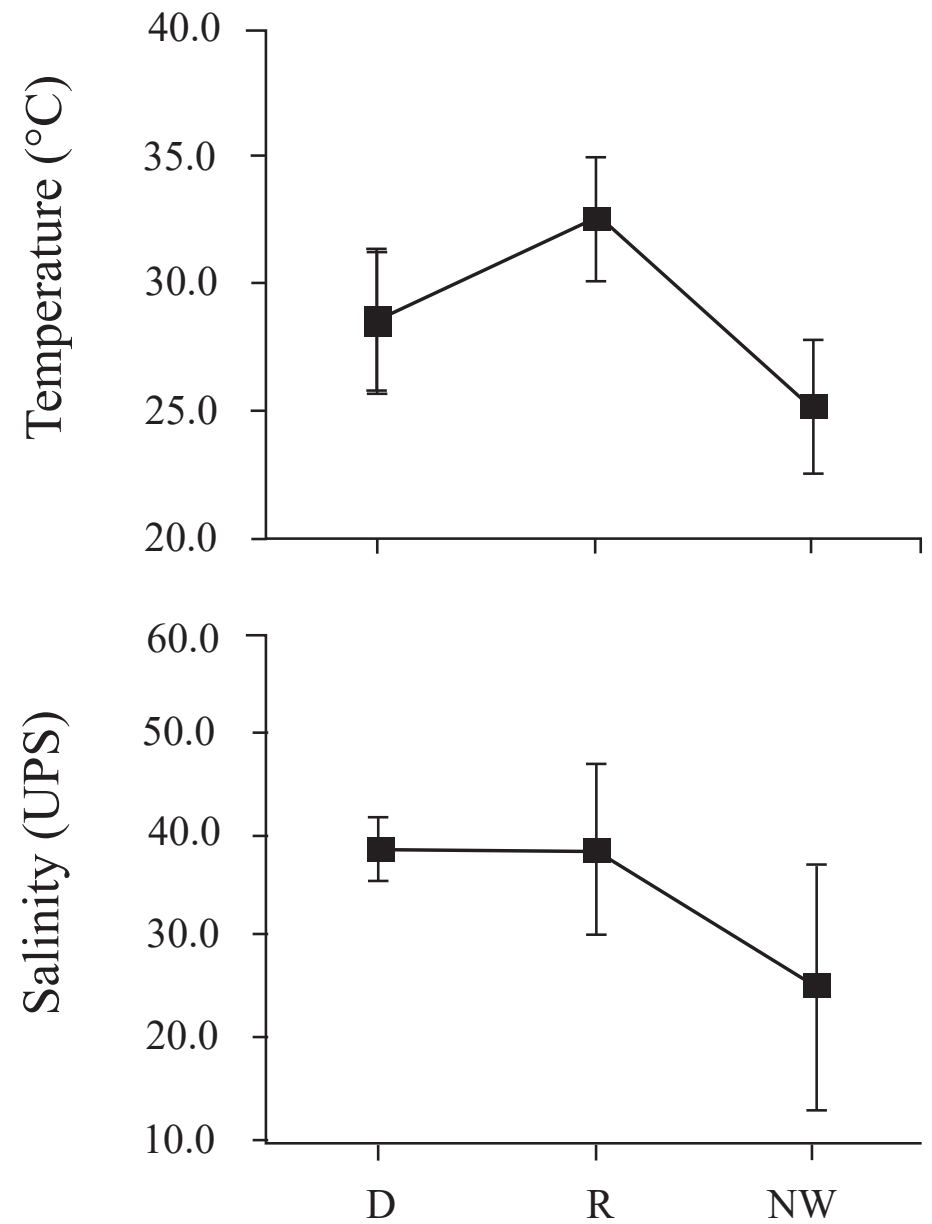

Fig. 2. Mean environmental variables ( \pm standard deviation) in the different climatic seasons in La Carbonera lagoon, Yucatan, Mexico

Fig. 2. Variables ambientales promedio ( \pm desviación estándar) en las diferentes temporadas climáticas en la laguna La Cabonera, Yucatán, México 
From the total specimens collected during this study, 1577 organisms of $E$. argenteus were most abundant $(>50 \%)$ during the dry season. On the other hand, in the sample of 2700 organisms of E. gula, a higher abundance (> $80 \%$ ) occurred during the rainy season (Fig. 3). However, abundance for both species was not statistically different (ANOVA, $F=1.70, P>0.05$ ) between climatic seasons.

The estimated parameters of LWR in E. argenteus were: $a=8.323 \mathrm{E}-03$ and $b=$ 2.92 , while in E. gula were: $a=7.314 \mathrm{E}-$ 03 and $b=2.92$ (Table 1). Exponent $b$ in the combined LWRs was not statistically different from the isometric value (E. argenteus: $t$-test $=-0.2145, P$
$>0.05 ;$ E. gula: -test $=-0.2316, P>$ 0.05 ) (Fig. 4). However, parameter $a$ showed differences between climatic seasons, given it was significantly higher during the dry season for E. argenteus and during the northerly winds season for E. gula. The values found for the coefficient of determination $\left(r^{2}\right)$ were $>$ 0.95 in the three climatic seasons in both species (Table 1).

The estimated equations of the VBGF for total length were: $L t=$ $13.65\left[1-\exp ^{-0.54(t-0.370)}\right]$ and $L t$ $=12.60\left[1-\exp ^{-0.68(t-0.283)}\right]$ for $E$. argenteus and E. gula, respectively. In addition, the monthly variation of the growth curve was estimated based on the length frequency data

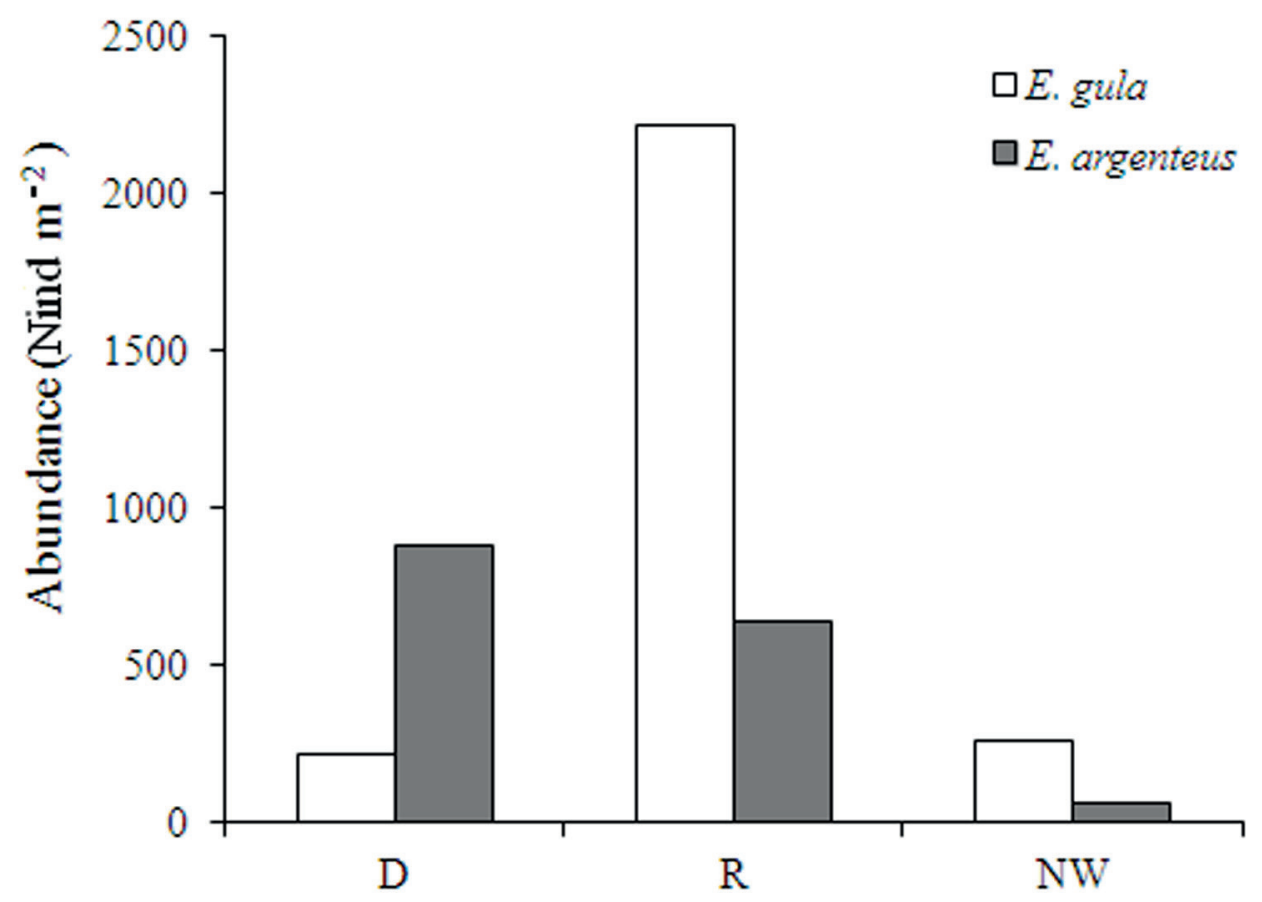

Fig. 3. Abundance (Ind $/ \mathrm{m}^{2}$ ) of E. gula and E. argenteus in the different climatic seasons in La Cabonera lagoon, Yucatan, Mexico

Fig. 3. Abundancia (Ind $/ \mathrm{m}^{2}$ ) de E. gula y E. argenteus en las diferentes temporadas climáticas en la laguna La Cabonera, Yucatán, México 
Table 1. Descriptive statistics and estimated parameters of length-weight relationships per season (dry, rainy and $\mathrm{NW}=$ north winds) and total of E. gula and E. argenteus en La Carbonera lagoon, Yucatan, Mexico

Cuadro 1. Estadística descriptiva y parámetros estimados de la relación talla-peso por temporada (secas, lluvias y NW = nortes) y total de E. gula y E. argenteus en la laguna La Carbonera, Yucatán, México

\begin{tabular}{|c|c|c|c|c|c|c|c|c|c|c|c|c|}
\hline \multirow[t]{2}{*}{ Species } & \multirow[t]{2}{*}{ Data } & \multirow[t]{2}{*}{$\mathbf{N}$} & \multicolumn{2}{|c|}{$\begin{array}{l}\text { Total } \\
\text { length } \\
(\mathrm{cm})\end{array}$} & \multicolumn{2}{|c|}{$\begin{array}{c}\text { Total } \\
\text { weight (g) }\end{array}$} & \multicolumn{6}{|c|}{ Regression parameters } \\
\hline & & & Min & $\operatorname{Max}$ & Min & Max & $a$ & $b$ & $\begin{array}{l}\text { SE } \\
(b)\end{array}$ & CI 95\% (a) & CI $95 \%(b)$ & $r^{2}$ \\
\hline \multirow{4}{*}{$\begin{array}{l}E . \\
\text { argenteus }\end{array}$} & Dry & 876 & 1.70 & 12.00 & 0.08 & 18.47 & $1.198 \mathrm{E}-02$ & 2.839 & 0.014 & $1.1 \mathrm{E}-03-1.2 \mathrm{E}-03$ & $2.812-2.868$ & 0.9889 \\
\hline & Rainy & 637 & 2.06 & 11.80 & 0.12 & 19.08 & $9.345 \mathrm{E}-03$ & 2.990 & 0.021 & 9.1E-03-9.5E-03 & $2.949-3.031$ & 0.9852 \\
\hline & NW & 64 & 3.50 & 11.00 & 0.57 & 15.07 & $9.436 \mathrm{E}-03$ & 2.917 & 0.057 & 8.9E-03-9.8E-03 & $2.804-3.030$ & 0.9885 \\
\hline & Total & 1577 & 1.70 & 12.00 & 0.08 & 19.08 & $8.323 \mathrm{E}-03$ & 2.922 & 0.011 & 8.2E-03-8.4E-03 & $2.899-2.944$ & 0.9774 \\
\hline \multirow{4}{*}{ E. gula } & Dry & 218 & 2.70 & 12.33 & 0.26 & 28.90 & $4.440 \mathrm{E}-03$ & 3.038 & 0.033 & 4.2E-03-4.6E-03 & $2.973-3.102$ & 0.9875 \\
\hline & Rainy & 2222 & 1.76 & 10.70 & 0.04 & 19.30 & $9.362 \mathrm{E}-03$ & 2.884 & 0.011 & 9.3E-03-9.4E-03 & $2.863-2.906$ & 0.9842 \\
\hline & NW & 260 & 3.20 & 9.00 & 0.43 & 8.35 & $1.152 \mathrm{E}-02$ & 2.990 & 0.043 & $1.1 \mathrm{E}-03-1.2 \mathrm{E}-03$ & $2.905-3.076$ & 0.9738 \\
\hline & Total & 2700 & 1.76 & 12.33 & 0.04 & 28.90 & $7.314 \mathrm{E}-03$ & 2.921 & 0.010 & 7.2E-03-7.4E-03 & $2.902-2.941$ & 0.9686 \\
\hline
\end{tabular}

$\mathrm{N}$, number of specimens considered in the analysis; $a$, scaling constant; $b$, slope; $\mathrm{CI}$, confidence intervals; $r^{2}$, coefficient of determination.

on both species (Fig. 5 and 6), and the growth performance index ( $f$ ') estimated was approximately 2.03 for E. gula and 2.00 for E. argenteus (Table 2).

The total instantaneous mortality rate $(Z)$ estimated by the lengthconverted catch curve in E. gula was 2.20 years $^{-1}(1.50-2.90 ; 95 \%$ confidence interval); however, in E. argenteus it was 1.75 years $^{-1}(0.07-3.43 ; 95 \%$ confidence interval). In contrast, the instantaneous natural mortality rate $(M)$ in E. gula was 1.50 years $^{-1}$ and in $E$. argenteus was 1.79 years $^{-1}$ in relation to the average temperature of the sampling period $\left(28.6^{\circ} \mathrm{C}\right)$.

\section{DISCUSSION}

It is interesting to find a marked impact of salinity and temperature on abundance throughout the study; when lower values were found, both

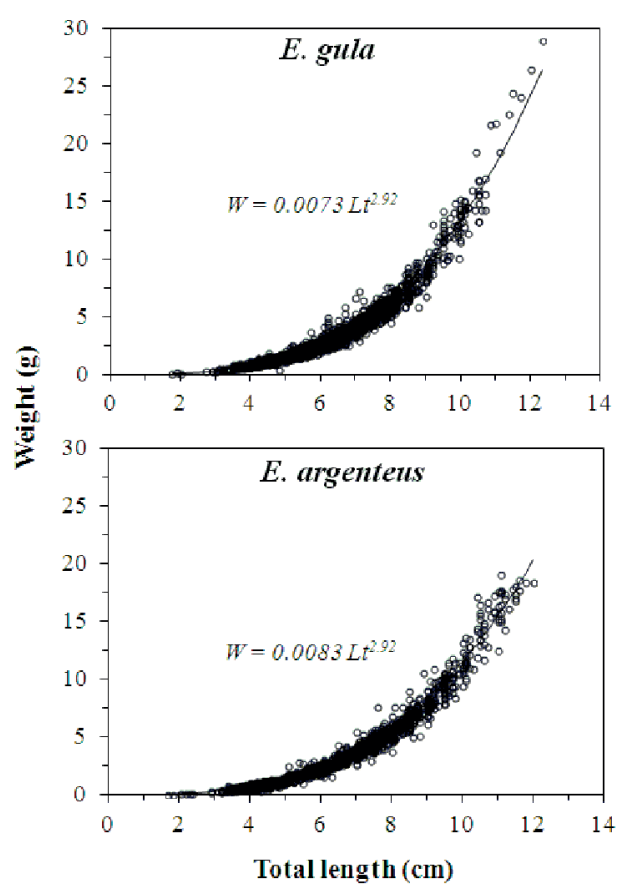

Fig. 4. Length-weight relationship (above) and $\log$-log plot (below) of E. gula and $E$. argenteus in La Carbonera lagoon, Yucatan, Mexico

Fig. 4. Relación peso-longitud (arriba) y logarítmica (abajo) de E. gula y E. argenteus en la laguna La Carbonera, Yucatán, México 


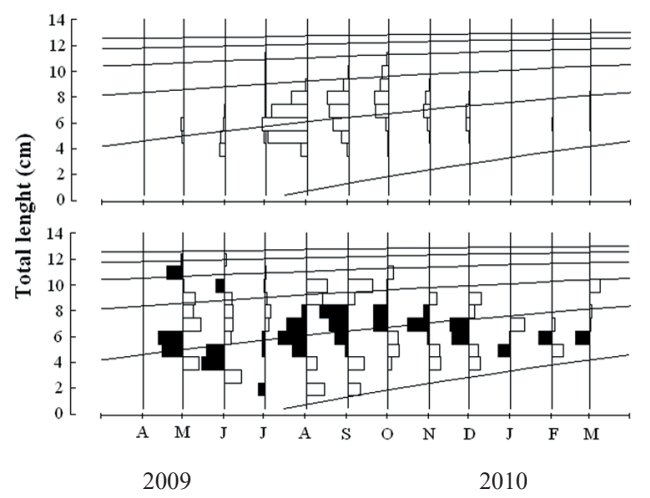

Fig. 5. Temporal variation of the growth curve based on length frequency data (above) and restructured length frequency data (below) computed in ELEFAN-I of E. gula from La Carbonera lagoon, Yucatan, Mexico

Fig. 5. Variación temporal de la curva de crecimiento basada en datos de frecuencias de longitudes (arriba) y en datos de frecuencia de longitud reestructurada computadas en ELEFAN-I para E. gula en la laguna La Carbonera, Yucatán, México

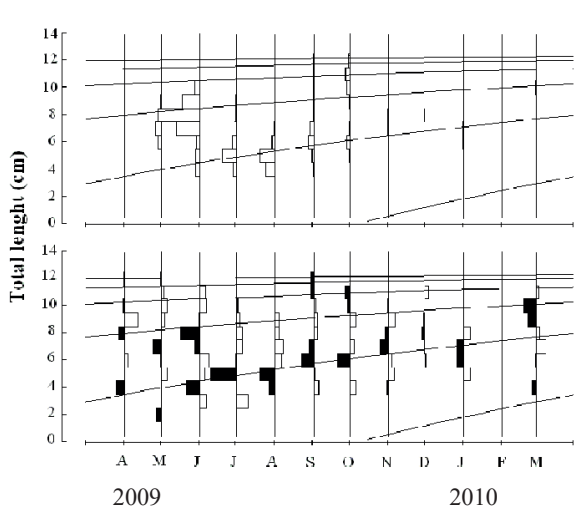

Fig. 6. Temporal variation of the growth curve based on length frequency data (above) and restructured length frequency data (below) computed in ELEFAN-I of E. argenteus from La Carbonera lagoon, Yucatan, Mexico

Fig. 6. Variación temporal de la curva de crecimiento basada en datos de frecuencias de longitudes (arriba) y en datos de frecuencia de longitud reestructurada computadas en ELEFAN-I para E. argenteus en la laguna La Carbonera, Yucatán, México

Table 2. Growth parameters of VBGF and growth performance index $\left(\phi^{\prime}\right)$ for E. gula and $E$. argenteus from La Carbonera lagoon, Yucatan, Mexico

Cuadro 2. Parámetros de crecimiento de la ECVB y el índice del desempeño del crecimiento $\left(\phi^{\prime}\right)$ para E. gula y E. argenteus en la laguna La Carbonera, Yucatán, México

\begin{tabular}{cccccc}
\hline Species & $\mathbf{N}$ & $\boldsymbol{L}_{\infty}(\mathbf{c m})$ & $\boldsymbol{k}\left(\mathbf{c m}\right.$ year $\left.{ }^{-1}\right)$ & $\boldsymbol{t}_{\boldsymbol{0}}($ year $)$ & $\phi$, \\
\hline E. argenteus & 1577 & 13.65 & 0.54 & -0.370 & 2.00 \\
E. gula & 2700 & 12.60 & 0.68 & -0.283 & 2.03 \\
\hline
\end{tabular}

$L_{\infty}$, asymptotic length; $k$, growth constant; $t_{0}$, hypothetical age at which the fish length is zero.

species studied decreased. However, higher temperatures were found during the rainy season and higher salinity during the dry season, when E. gula and E. argenteus respectively occurred most abundantly. Similar results were found by Arceo-Carranza \& VegaCendejas (2009) with the same species in another coastal lagoon of Yucatan. However, Pacheco et al. (2010) suggest that environmental conditions are important determinants of spatial distribution and size of $E$. argenteus during the dry season in the north zone of the Colombian Caribbean Sea, with temperature and depth as variables that better predict the spatial distribution of this species. Despite the environmental variability of this region, La Carbonera coastal lagoon provides a favorable habitat for E. gula and E. argenteus, irrespective of the shallowness by 
season (Bonilla-Gómez et al. 2011). Therefore, salinity and temperature prompted a shift in abundances by season, especially when north winds prevailed. A similar trend is reported for both studied species in another coastal system (Arceo-Carranza et al. 2013).

Growth parameters for E. gula and $E$. argenteus showed the exponent $b$ around 2.92, indicating a preference for isometric relationships. Similar results were found by Vega-Cendejas et al. (2012) in another coastal lagoon in the northwestern Yucatan peninsula. In addition, the LWR exponent remains close to isometric growth, showing that those species have a proportional volume growth. This isometric growth could be attributed to food availability, low density, and productivity characterizing the study area, with productivity being in its highest during the rainy season (Herrera, 1988).

VBGF parameters for both species have not been previously reported in the Yucatan peninsula. According to the results of the growth performance index ( $f^{\prime}=2.03$ ), both species on the coast of the Yucatan peninsula have a lower growth rate compared to the one reported by García \& Duarte (2006) on the Caribbean coast of Colombia $(E$. gula, $\mathrm{f}^{\prime}=2.16 ;$ E. argenteus, $\left.\mathrm{f}^{\prime}=2.39\right)$. This could be related to the uncertainty associated with the growth rate $(k)$ estimates by the length frequency analysis. Pauly (1979) and Sparre \& Venema (1995) determine that the coefficient of variation of $f$ ' should not exceed $4 \%$ for growth patterns to be considered statistically similar.
This study presents the first estimates of mortality for E. gula and E. argenteus in the Yucatan Peninsula. Estimates of total mortality by the length-converted catch curve (Pauly, 1983) are equivalent to the natural mortality rate $(Z=M)$ due to the absence of fishing of this species in the study area. Differences in natural mortality can be attributed to latitudinal dissimilarities according to Bravo et al. (2009), who reported that variations of these parameters could be due to growth differences associated to species present at different latitudes.

\section{CONCLUSIONS}

Abundance was the lowest in $E$. argenteus and E. gula when salinities and temperature occurred with the lowest values, especially during the northerly winds season. The LWR in $E$. argenteus and E. gula showed an isometric growth. Growth parameters of the VBGF in E. argenteus were: $L_{\infty}$ $=13.65 \mathrm{~cm}, k=0.54$ year $^{-1}$ and $t_{0}=$ - 0.37 years, while in E. gula were: $L_{\infty}=12.60 \mathrm{~cm}, k=0.68$ year $^{-1}$ and $t_{0}$ $=-0.28$ years. The natural mortality in E. gula was 1.50 years $^{-1}$ and in E. argenteus was 1.9 years $^{-1}$. The information provided in this study on the basic parameters of the population dynamics of E. gula and E. argenteus represents fundamental knowledge of both species to implement the measures and strategies for their management and conservation in an important coastal area of the Yucatan peninsula. 


\section{ACKNOWLEDGEMENTS}

This investigation was supported by PAPIIT (IN207609, IN213012) and FOMIX-Yucatan (103229) research grants. We thank Korynthia López, Carmen Galindo, Joel Loera, Juani Tzeek, Héctor Gutiérrez, Daniel Arceo, and all the members of La Carbonera project team for their technical support during research. We also want to express our gratitude to Chelsea Combest-Friedman whose comments improved and enriched this manuscript. In addition, J. L. Bonilla-Gómez is grateful to the Consejo Nacional de Ciencia y Tecnología de México (CONACyT) for the scholarship awarded to pursue doctoral studies (CVU/Becario: $178371 / 240833$ ) in the Marine Sciences and Limnology Graduate Program at Universidad Nacional Autónoma de México (UNAM).

\section{REFERENCES}

Arceo-Carranza, D. \& Vega-Cendejas, M. E. (2009). Spatial and temporal characterization of fish assemblages in a tropical coastal system influenced by freshwater inputs: northwestern Yucatan peninsula. Rev. Biol. Trop., 57(12), 89-103.

Arceo-Carranza, D., Vega-Cendejas, M. E. \& Hernández de Santillana, M. J. (2013). Day and night trophic variations of dominant fish species in a lagoon influenced by freshwater seeps. J. Fish. Biol., 82(1), 54-68.

Batllori-Sampedro, E., González-Piedra, J. I., Díaz-Sosa, J. \& Febles-Patrón, J.
L. (2006). Caracterización hidrólogica de la región costera noroccidental del estado de Yucatán, México. Invest. Geog., 59, 74-92.

Bonilla-Gómez, J. L., López-Rocha, J., Badillo-Alemán, M., Tzeek-Tuz, J. \& Chiappa-Carrara, X. (2011). Growth and mortality of Lagodon rhomboides (Pisces: Sparidae) in a tropical coastal lagoon in northwestern Yucatan, Mexico. Rev. Mar. Cost., 3, 99-109.

Bonilla-Gómez, J. L., Tzeek-Tuz, J., Badi1lo, M. \& Chiappa-Carrara, X. (2012). Growth and mortality of Sphoeroides testudineus (Tetraodontiformes: Tetraodontidae) in a tropical coastal lagoon in northwestern Yucatán Peninsula. Rev. Mex. Biodiver., 83(4), 1237-1240.

Bravo, E., Eslava, N. \& González, L. (2009). Crecimiento y mortalidad natural del pez Haemulon aerolineatum (Teleostei: Haemulidae) del suroeste de la isla Margarita, Venezuela. Rev. Biol. Trop., 57(3), 699-706.

Castillo-Rivera, M., Zavala-Hurtado, J. A. \& Zárate, R. (2002). Exploration of spatial and temporal patterns of fish diversity and composition in a tropical estuarine system of Mexico. Rev. Fish. Biol. Fisher, 12(2-3), 167-177.

Froese, R. (2006). Cube law, condition factor and weight-length relationships: history, meta-analysis and recommendations. J. Appl. Ichthyol., 22(4), 241-253.

García, C. B. \& Duarte, L. O. (2006). Length-based estimates of growth parameters and mortality rates of fish populations of the Caribbean Sea. $J$. Appl. Ichthyol., 22(3), 193-200.

Gayanilo, F. C. Jr., Sparre, P. \& Pauly, D. (2005). FAO-ICLARM Stock Assessment Tools II (FiSAT II). FAO Computerized Information Series (Fisheries). No. 8. Rome, Italy: FAO. 
Godefroid, R., Santos, C., Hofstaetter, M. \& Spach, L. (2001). Occurrence of larvae and juveniles of Eucinostomus argenteus, Eucinostomus gula, Menticirrhus americanus, Menticirrhus littorals, Umbrina coroides and Micropogonias furnieri at Pontal do Sul beach, Paraná. Braz. Arch. Biol. Tech., 44(4), 411-418.

Herrera, J. (1988). Productividad primaria ictioplanctónica del estero de Celestún, Yucatán, durante el periodo octubre 1983-abril 1984. Unpublished master thesis, Universidad Autónoma de Guadalajara, Jalisco.

Kerschner, B.A., Peterson, M. S. \& Gilmore, R.G. Jr. (1985). Ecotopic and ontogenetic trophic variation in mojarras (Pisces: Gerreidae). Estuaries, 8, 311-322.

Lankford, R. R. (1977). Coastal lagoons of Mexico: Their origin and classification. In M. Wiley (Ed.), Estuarine Processes (pp. 182-215). New York, EE.UU.: Academic Press.

Munro, J. L. \& Pauly, D. (1983). A simple method for comparing growth of fishes and invertebrates. ICLARM Fishbyte, 1(1), 5-6.

Ordóñez-López, U. \& García-Hernández, V. (2005). Ictiofauna juvenil asociada a Thalassia testudinum en la laguna Yalahau, Quintana Roo. Hidrobiológica, 15(2), 195-204.

Pacheco, M., Páramo, J. \& Sánchez, C. (2010). Estructura especial de Eucinostomus argenteus (Pisces: Gerreidae) en la zona norte del Caribe Colombiano. Acta Biol. Colomb., 15(1), 179-194.

Pauly, D. (1979). Theory and management of tropical multispecies stocks: A review with emphasis on the Southeast Asian demersal fisheries. ICLARM Stud. Rev., 1, 1-35.

Pauly, D. (1980). On the interrelationships between natural mortality, growth parameters and mean environmental temperature in 175 fish stocks. J. Cons. CIEM., 39(3), 175-192.

Pauly, D. (1983). Some simple methods for the assessment of tropical fish stocks. Rome, Italy.: FAO. Fish. Tech. Pap.

Pauly, D. (1990). Length-converted catch curves and the seasonal growth of fishes. Fishbyte, 8(3), 33-38.

Pitcher, T. J. \& Hart, P. J. B. (1982). Fisheries ecology. London, England: Chapman and Hall.

Shervette, V. R., Ibarra, N. \& Gelwick, F. (2007). Influences of salinity on growth and survival of juvenile pinfish Lagodon rhomboides (Linnaeus). Environ. Biol. Fish., 78(2), 125-134.

Sparre, P. \& Venema, S. (1995). Introducción a la evaluación de los recursos pesqueros tropicales. FAO Doc. Téc. Pesca 306/1. Rome, Italy: FAO.

Vega-Cendejas, M. E., de Santillana, M. H. \& Arceo, D. (2012). Length-weight relationships for selected fish species from a coastal lagoon influenced by freshwater seeps: Yucatan peninsula, Mexico. $J$. Appl. Ichthyol., 28(1), 140-142. 